\title{
Classic homocystinuria
}

INSERM

\section{Source}

INSERM. (1999). Orphanet: an online rare disease and orphan drug data base. Classic homocystinuria. ORPHA:394

Classical homocystinuria due to cystathionine beta-synthase (CbS) deficiency is characterized by the multiple involvement of the eye, skeleton, central nervous system, and vascular system. 